\title{
Diversity and partial characterization of putative virulence determinants in Pasteuria penetrans, the hyperparasitic bacterium of root-knot nematodes (Meloidogyne spp.)
}

\author{
K.G. Davies and M. Redden \\ Entomology and Nematology Department, Rothamsted Experimental Station, Harpenden, Hertfordshire, UK \\ 5890/08/96: received 21 August 1996, revised 13 December 1996 and accepted 20 December 1996
}

K.G. DAVIES AND M. REDDEN. 1997. Antigens recognized by monoclonal antibodies (Mabs) raised to the surface of the obligate nematode hyperparasite Pasteuria penetrans were characterized. Using the attachment of spores of the bacterium to host nematodes to determine the biological variability present on the spore surface greatly underestimated the amount of surface heterogeneity present compared with estimates from immunological techniques. This heterogeneity differed not only between different individual spores from the same population but also between different spore populations. None of the Mabs completely inhibited any spore population from attaching to the nematode cuticle, suggesting that the mechanism of attachment may be more complex than previously supposed. Chemical degradation of one particular epitope recognized by monoclonal antibody PP1/117, and designated ep117, occurred after treatment with $\mathrm{NaOH}$, periodate or Proteinase K, suggesting that an O-linked glycoprotein may be involved. Fibronectin, which had been found to bind to Pasteuria spores through hydrophobic interactions, also prohibited the Mab from recognizing ep117. However, SDS-PAGE of spore extracts followed by immunoblotting showed that none of the Mabs could detect this epitope and so ep117 may be conformational in nature. Thus, the conformation of any particular epitope recognized by a Mab may be important in determining to which nematode a particular spore will attach. The distribution of a particular epitope within a population of spores will in turn therefore determine its virulence on a particular nematode.

\section{INTRODUCTION}

The Pasteuria group of Gram-positive endospore-forming bacteria are hyperparasites of plant-parasitic nematodes and water fleas (Daphnia spp.). The taxonomy of these hyperparasites remains unclear but they are probably made up of a number of species and isolates which differ in their host ranges and virulence. Four species of Pasteuria have been described so far: (1) P. penetrans parasitic on Meloidogyne incognita and probably other root-knot nematodes (Sayre and Starr 1985); (2) P. thornei on Pratylenchus brachyurus (Sayre and Starr 1988); (3) P. nishizamae which parasitizes cyst nematodes (Sayre et al. 1991); and (4) P. ramosa, a parasite of water fleas Daphnia spp. (Sayre et al. 1983). All the econ-

Correspondence to: Dr K.G. Davies, Entomology and Nematology

Department, IACR Rothamsted, Harpenden, Hertfordshire AL5 27Q, UK. omically important genera of plant-parasitic nematodes have an association with these bacteria (Sayre and Starr 1988), and the most significant is $P$. penetrans as it has potential to control root-knot nematodes (Stirling 1991; Oostendorp et al. 1991), economically the most devastating plant-parasitic nematodes of tropical and subtropical crops (Luc et al. 1988).

A major obstacle to the commercial development of these nematode hyperparasites, as biological control agents, is the limited host range of individual species and isolates; isolates of $P$. penetrans have been found which adhere only to a particular species of root-knot nematode and some which adhere to only individual populations within a species (Stirling 1985; Channer and Gowen 1992; Davies and Danks 1992). Nematodes often occur as mixed populations, and their cuticles have been shown to exhibit polymorphism (Davies and Danks 1992) so the deployment of an isolate not 
compatible with the nematode populations present would undoubtedly lead to a failure to control the nematodes. As detectable polymorphism is a poor guide to the underlying biochemistry of recognition (Frank 1994) it is important to understand the mechanism by which the bacteria adhere to their host nematode in order to assess their biological variability. The recognition process, by which spores of the bacterium bind to the nematode cuticle, is the first stage in a sequence of events which ultimately lead to infection and is poorly understood. The pretreatment of bacterial spores with a series of enzymes, lectins and sugars suggested that $N$ acetylglucosamine on the spore surface was acting as an adhesin (Bird et al. 1989; Davies and Danks 1993). Physicochemical investigations of the spore surface suggest that the binding of the spore to the nematode cuticle probably involves hydrophobic interactions (Afolabi et al. 1995). Several monoclonal antibodies (Mabs) raised to a population of Pasteuria spores from a nematode cultured from a single egg mass showed that the surface of spores was highly heterogeneous. Different sub-populations of spores recognized different nematode populations, indicating that the different nematode populations were also heterogeneous (Davies et al. 1994). The present study investigates the heterogeneity present in several populations of $P$. penetrans spores from different geographical areas using these same Mabs and biochemically characterizes one particular epitope on the spore which was thought to be involved in adhesion.

\section{MATERIALS AND METHODS}

\section{Nematodes and bacterial cultures}

A single egg mass line of Meloidogyne incognita race 2 (originating from North Carolina State University) was cultured in a glasshouse at $25^{\circ} \mathrm{C}$ on tomato plants, cv. Pixie, in a peat/sand (1:1, v/v) compost. Second-stage juveniles were hatched from egg masses by placing them in tap water on a small tray at room temperature (Hooper 1986). Populations of Pasteuria penetrans from several geographical locations (Table 1) were cultured on $M$. incognita race 2 using the method of Stirling and Wachtel (1980) and the tomato root powder produced was stored dry at $4^{\circ} \mathrm{C}$. Suspensions of spores were prepared by grinding Pasteuria-infested tomato root powder in tap water with a pestle and mortar, and the spores filtered through a $10 \mu \mathrm{m}$ sieve before they were counted using a haemocytometer slide. The concentrations of the suspensions were adjusted to $10^{6}$ spores $\mathrm{ml}^{-1}$.

\section{Antibody production and characterization}

Mice (Balb/C) were immunized with suspensions of spores of $P$. penetrans population PP1 $\left(10^{7}\right.$, concentrated by centrifugation); after 3 weeks, $50 \mu$ l blood samples were obtained and tested for their ability to recognize the surface of spores of $P$. penetrans (PP1) by immunofluorescence (see below). A mouse exhibiting a strong immunological response to the bacterium was subsequently boosted with a further $10^{7}$ spores (PP1) $4 \mathrm{~d}$ prior to fusion. All injections were administered into the peritoneum in $0.5 \mathrm{ml}$ of PBS. At the time of the splenectomy a cardiac puncture was done and the serum collected (Harlow and Lane 1988). Production of Mabs for the spores has been described elsewhere (Davies et al. 1994). Antibodies were isotyped using a mouse monoclonal antibody isotyping kit (Sigma).

\section{Immunofluorescence using Mabs and wheat germ agglutinin (WGA)}

Bacterial spores ( $15 \mu \mathrm{l}$ of tomato root suspensions) (Table 1 ) were allowed to adhere to multitest slides coated with poly1-lysine (Harlow and Lane 1988). After washing in PBS (3 times) spores were blocked with 20-DMEM for $30 \mathrm{~min}$ and then incubated with Mabs in tissue culture supernatant fluid or WGA (1:50) conjugated to fluorescein isothiocyanate (FITC) (Sigma) for $2 \mathrm{~h}$, after which they were rewashed (3 times). The Mabs were then detected by a further incubation for $2 \mathrm{~h}$ with goat antimouse antiserum (1:50) conjugated to FITC at $37^{\circ} \mathrm{C}$ followed by 3 washes. After incubation in the FITC conjugate and washing, the spores were mounted in

\begin{tabular}{lll}
\hline Pasteuria & Geographical origin & Source \\
\hline PP1 & California, USA & Dr S.R. Gowen, University of Reading, UK \\
PP3O & South Africa & Dr S.R. Gowen \\
PP3A & South Africa & Dr S.R. Gowen \\
PPA & Maryland, USA & Dr R.M. Sayre, USDA, Beltsville, USA \\
PPB7 & California, USA & Dr G.R. Stirling, DPI, Indooroopilly, Australia \\
PPD & Queensland, Australia & Dr G.R. Stirling \\
PPE & Queensland, Australia & Dr G.R. Stirling \\
PCAL & California, USA & Dr S. Verdejo-Lucas, IRTA, Barcelona, Spain \\
PNG & Papua New Guinea & Dr J. Bridge, CABI, St Albans, UK \\
\hline
\end{tabular}

Table 1 Source and geographical origin of Pasteuria penetrans populations 
Citifluor $^{\text {TM }}$ (Agar Scientific, Stansted, UK). All preparations were examined using an Olympus BH-2 microscope fitted with epifluorescence illumination with a $455 \mathrm{~nm}$ excitation filter and a $520 \mathrm{~nm}$ barrier filter. From the results of the immunofluorescence experiments a similarity matrix was constructed and a hierarchical, single linkage, cluster analysis was computed using the method of Digby and Kempton (1987); all computations were undertaken using GENSTAT 5 (Anon. 1987).

\section{Spore inhibition assay}

Five hundred $\mu \mathrm{l}$ samples of spore suspensions of each of the stock Pasteuria populations were placed in separate siliconized Eppendorf tubes and spun ( $10000 \mathrm{~g}$ for $5 \mathrm{~min})$ and the supernatant fluids removed. The spores were then resuspended in $200 \mu \mathrm{l}$ of each of the Mabs in tissue culture supernatant fluid and incubated for $1 \mathrm{~h}$ at $37^{\circ} \mathrm{C}$; control samples were incubated as above in tissue culture supernatant fluid. Following incubation the spores were washed $(\times 3)$ by repeated spinning and resuspension in PBS. After the final spin the spores were resuspended in $500 \mu \mathrm{l}$ of water to which were added 500 freshly hatched second-stage juveniles of $M$. incognita and an attachment test was performed by centrifugation (Hewlett and Dickson 1993). The number of spores adhering to 20 nematodes was then counted using a light microscope $(\times 400)$

\section{Immunological characterization of spore antigens}

Polyacrylamide gel electrophoresis and immunoblotting. Polyacrylamide gel electrophoresis in the presence of sodium dodecylsulphate (SDS-PAGE) was performed using a $12 \%$ (w/v) separating gel ( $\mathrm{pH} 8.8)$ and 4\% (w/v) stacking gel (pH $6 \cdot 8)$. Spores of Pasteuria $\left(10^{6}\right)$, from each population, were suspended in $200 \mu \mathrm{l}$ of sample buffer $\left(50 \mathrm{mmol} \mathrm{l}^{-1}\right.$ Tris/ $\mathrm{HCl}, \mathrm{pH} 6 \cdot 8,2 \%$ SDS w/v, 2\% 2-ME, 10\% glycerol and $0.002 \%$ bromophenol blue $\mathrm{w} / \mathrm{v}$ ) and heated for $2 \mathrm{~min}$ at $100^{\circ} \mathrm{C}$ before $20 \mu \mathrm{l}$ of the solution was loaded onto the stacking gel. Prestained SDS-PAGE molecular weight markers (Sigma; Cat. No. SDS-7B) were run on each gel. After electrophoresis, the gel slabs were electro-blotted onto nitrocellulose membranes (BioRad) in continuous buffer (Harlow and Lane 1988) using a Semi-phor ${ }^{\text {TM }}$ blotting system (Hoeffer Scientific Instruments, Newcastle-under-Lyme, UK). Membranes were blocked with 2\% BSA in PBST (2\% bovine serum albumen w/v and $0.05 \% \mathrm{v} / \mathrm{v}$ Tween in PBS). Following transfer and blocking, the blots were probed with either polyclonal antiserum (obtained from the cardiac puncture), 1:500 in 5\% blotto (Harlow and Lane 1988), or each of the Mabs in tissue culture supernatant fluid. After washing $(\times 2)$ in PBS, membranes were incubated with rabbit antimouse IgG alkaline phosphatase conjugate (1:500 in $5 \%$ blotto for $2 \mathrm{~h}$ ). After a further two washes the membranes were incubated in alkaline phosphate substrate $(0.03 \% \mathrm{w} / \mathrm{v}$ nitro blue tetrazolium, $0 \cdot 02 \% \mathrm{w} / \mathrm{v} 5$-bromo-4-chloro-3-indolyl phosphate, in Tris/ $\mathrm{HCl}, \mathrm{pH} 9 \cdot 5$ substrate buffer); the reaction was terminated with several washes in distilled water.

\section{Experimental}

Characterization of Pasteuria epitope recognized by Mab PP1/117 (ep117). Spores were subjected to several physical, chemical and enzymic treatments to characterize the biochemical nature of ep117. (a) $500 \mu \mathrm{l}$ of spores (PP1) were (1) heated to $100^{\circ} \mathrm{C}$ for $3 \mathrm{~min}$ to denature protein; (2) incubated in $0 \cdot 1 \mathrm{~mol} 1^{-1} \mathrm{NaOH}$ at $25^{\circ} \mathrm{C}$ for $60 \mathrm{~min}$ which cleaves $O$ linked and some $N$-linked oligosaccharides (Maizels et al. 1991); (3) incubated with 5\% w/v trichloroacetic acid (TCA) at $4^{\circ} \mathrm{C}$ for $24 \mathrm{~h}$ to extract lipoteichoic acid (Hancock and Poxton 1988); (4) incubated in $25 \mathrm{mmol}^{-1}$ sodium metaperiodate in $100 \mathrm{mmol}^{-1}$ sodium acetate buffer at $\mathrm{pH} 5.0$ in the dark at $4^{\circ} \mathrm{C}$ for $30 \mathrm{~min}$ to break the ring structure of hexcose (Maizels et al. 1991). (b) Spores (PP1) were allowed to adhere to microscope slides (as above) and were then subjected to one of the following enzymic degradation treatments: trypsin, type II, $1540 \mathrm{U} \mathrm{ml}^{-1}$; Proteinase $\mathrm{K}, 14 \mathrm{U}$ $\mathrm{ml}^{-1}$; muramidase (egg white), $62500 \mathrm{U} \mathrm{ml}^{-1}$; chitinase, $0 \cdot 5 \mathrm{U} \mathrm{ml}^{-1}$; neuraminidase, type $\mathrm{V}, 1 \cdot 1 \mathrm{U} \mathrm{ml}^{-1}$; galactosidase grade VI, $450 \mathrm{U} \mathrm{ml}^{-1}$; hyaluronidase type I-S, $290 \mathrm{U} \mathrm{ml}^{-1}$. Enzyme treatments were carried out in Tris/ $\mathrm{HCl}(50 \mathrm{mmol}$ $\left.1^{-1}, \mathrm{pH} 7 \cdot 2\right)$ at $37^{\circ} \mathrm{C}$ for $2 \mathrm{~h}$, with the exception of neuraminidase which was in sodium acetate $\left(100 \mathrm{mmoll}^{-1}, \mathrm{pH}\right.$ $5 \cdot 0)$. (c) Spores (PP1) were also incubated for $2 \mathrm{~h}$ at $37^{\circ} \mathrm{C}$ with fibronectin, $50 \mu \mathrm{g} \mathrm{ml}^{-1}$, wheat germ agglutinin (WGA), $50 \mu \mathrm{g} \mathrm{ml}^{-1}$, and a series of $0 \cdot 2 \mathrm{~mol} \mathrm{l}^{-1}$ sugars (fucose, $N$ acetylglucosamine (NAG), mannose, xylose and galactose in 20-DMEM). After treatments the spores were washed thoroughly in PBS $(\times 3)$ and indirect immunofluorescence was carried out using Mab PP1/117 as above. Several of these treatments described above had previously been found to affect spore attachment to nematode cuticle (Davies and Danks 1993).

\section{RESULTS}

\section{Immunoprofiles of Pasteuria spore surface}

The immunoprofiles of the different populations of Pasteuria probed with each of the Mabs, all of which were IgM antibodies, by indirect immunofluorescence showed that each population was very different (Table 2); WGA recognized all spores to some degree in populations PPA, PPB7, PP3O and even in the other populations tested WGA recognized at least $90 \%$ of the spores. This contrasts with Mab PP1/84 which recognized less than $10 \%$ of all the spores tested, usually 


\begin{tabular}{|c|c|c|c|c|}
\hline $\begin{array}{l}\text { Pasteuria } \\
\text { population }\end{array}$ & $\begin{array}{l}\text { Monoclonal } \\
\text { antibody }\end{array}$ & $\begin{array}{l}\text { No } \\
\text { recognition }\end{array}$ & $\begin{array}{l}\text { Weak } \\
\text { recognition }\end{array}$ & $\begin{array}{l}\text { Strong } \\
\text { recognition }\end{array}$ \\
\hline \multirow[t]{6}{*}{ PP1 } & $\mathrm{PP} 1 / 12$ & 0 & 30 & 0 \\
\hline & $\mathrm{PP} 1 / 53$ & 5 & 18 & 7 \\
\hline & $\mathrm{PP} 1 / 84$ & 27 & 1 & 2 \\
\hline & $\mathrm{PP} 1 / 117$ & 9 & 21 & 0 \\
\hline & PP1/134 & 2 & 28 & 0 \\
\hline & WGA & 2 & 17 & 11 \\
\hline \multirow[t]{6}{*}{ PPA } & PP1/12 & 10 & 20 & 0 \\
\hline & $\mathrm{PP} 1 / 53$ & 30 & 0 & 0 \\
\hline & PP1/84 & 11 & 17 & 2 \\
\hline & PP1/117 & 1 & 6 & 23 \\
\hline & $\mathrm{PP} 1 / 134$ & 7 & 23 & 0 \\
\hline & WGA & 0 & 22 & 8 \\
\hline \multirow[t]{6}{*}{ PPB7 } & $\mathrm{PP} 1 / 12$ & 7 & 23 & 0 \\
\hline & $\mathrm{PP} 1 / 53$ & 0 & 12 & 18 \\
\hline & $\mathrm{PP} 1 / 84$ & 30 & 0 & 0 \\
\hline & PP1/117 & 0 & 30 & 0 \\
\hline & PP1/134 & 30 & 0 & 0 \\
\hline & WGA & 0 & 10 & 20 \\
\hline \multirow[t]{6}{*}{ PPD } & PP1/12 & 1 & 28 & 1 \\
\hline & $\mathrm{PP} 1 / 53$ & 18 & 10 & 2 \\
\hline & $\mathrm{PP} 1 / 84$ & 30 & 0 & 0 \\
\hline & $\mathrm{PP} 1 / 117$ & 26 & 2 & 2 \\
\hline & PP1/134 & 1 & 29 & 0 \\
\hline & WGA & 3 & 15 & 12 \\
\hline \multirow[t]{6}{*}{ PPE } & $\mathrm{PP} 1 / 12$ & 3 & 27 & 0 \\
\hline & $\mathrm{PP} 1 / 53$ & 5 & 6 & 19 \\
\hline & $\mathrm{PP} 1 / 84$ & 30 & 0 & 0 \\
\hline & PP1/117 & 2 & 5 & 23 \\
\hline & PP1/134 & 4 & 26 & 0 \\
\hline & WGA & 1 & 21 & 8 \\
\hline \multirow[t]{6}{*}{ PP3O } & $\mathrm{PP} 1 / 12$ & 11 & 19 & 0 \\
\hline & $\mathrm{PP} 1 / 53$ & 2 & 13 & 15 \\
\hline & $\mathrm{PP} 1 / 84$ & 30 & 0 & 0 \\
\hline & PP1/117 & 0 & 17 & 13 \\
\hline & PP1/134 & 0 & 30 & 0 \\
\hline & WGA & 0 & 8 & 22 \\
\hline \multirow[t]{6}{*}{ PP3A } & PP1/12 & 0 & 30 & 0 \\
\hline & $\mathrm{PP} 1 / 53$ & 30 & 0 & 0 \\
\hline & $\mathrm{PP} 1 / 84$ & 30 & 0 & 0 \\
\hline & $\mathrm{PP} 1 / 117$ & 29 & 1 & 0 \\
\hline & $\mathrm{PP} 1 / 134$ & 0 & 30 & 0 \\
\hline & WGA & NA & NA & NA \\
\hline
\end{tabular}

Table 2 Indirect

immunofluorescence of 30 spores of seven populations of Pasteuria penetrans (PP1, PPA, PPB7, PPD, PPE, PP3O and PP3A) with five monoclonal antibodies (PP1/12, PP1/53, PP1/84, $\mathrm{PP} 1 / 117$ and PP1/134) and the lectin wheat germ agglutinin (WGA) assessed as : no recognition, weak recognition or strong recognition

NA, Not available.

irrespective of the source of the population of Pasteuria; the only exception was PPA where PP1/84 recognized $63 \%$ of the population. The rest of the Mabs fell between these two extremes and their ability to recognize the spore surface 
was used in hierarchical cluster analysis to characterize their overall similarities; a dendrogram was constructed (Fig. 1). Pasteuria populations PPD and PP3A were the most closely related showing just less than $85 \%$ similarity. These two populations were linked to a group of three other populations, comprising PPE, PP3O and PP1, showing a similarity of about $70 \%$. The two other populations, PPA and PPB7, showed similarities of less than $60 \%$.

\section{Inhibition of attachment to Meloidogyne incognita}

Pre-incubation of the spores in the Mabs prior to attachment had no significant effect on PPA, PPB7 and PPD. However, all the Mabs reduced the attachment of spore populations PP1 and PP3O with the exception of PP1/84 with spore population PP1; Mabs PP1/53, PP1/117 and PP1/134 reduced attachment of spore population PPE (Table 3 ). No Mab recognized an epitope which inhibited attachment completely; even Mab PP1/117, which exhibited preferential

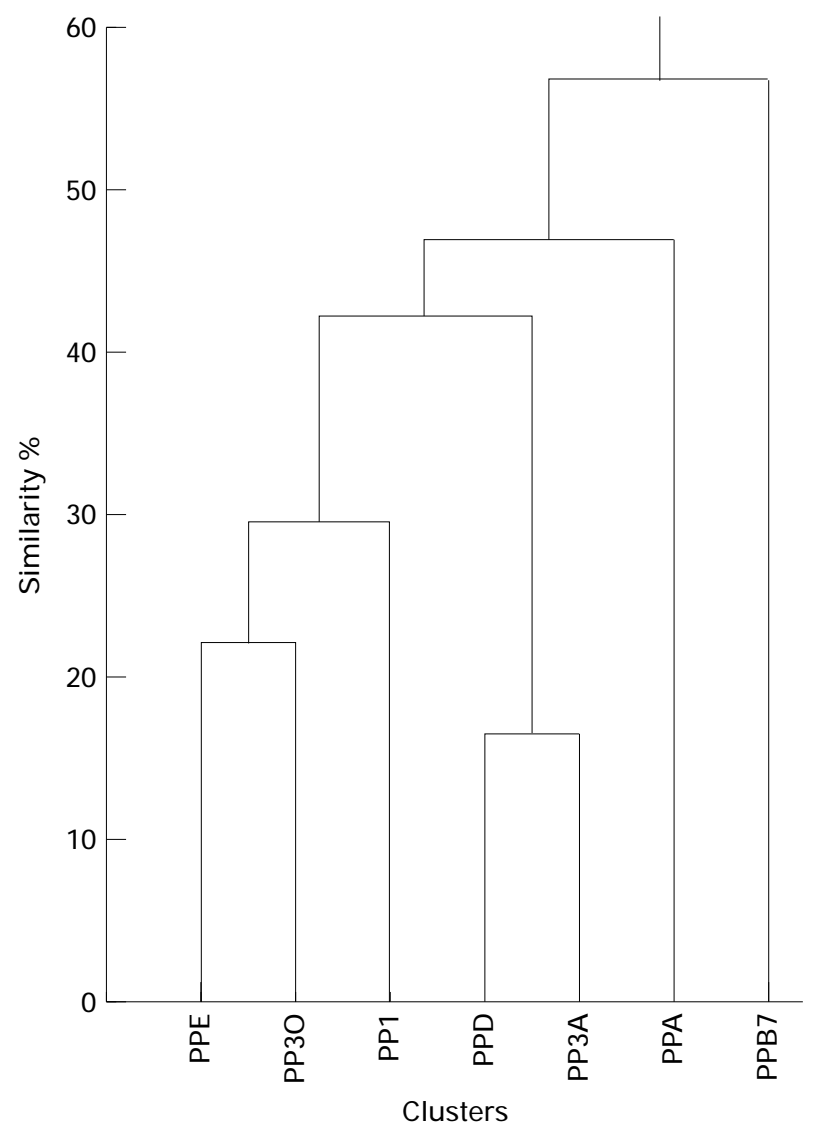

Fig. 1 Dendrogram resulting from data produced from a single, immunofluorescence experiment, and constructed from a similarity matrix produced by a hierarchical, single linkage analysis of populations of spores of Pasteuria penetrans from different geographical regions
Table 3 The mean number of spores of six populations of Pasteuria penetrans (PP1, PPA, PPB7, PPD, PPE and PP3O) adhering to second-stage juveniles of Meloidogyne incognita after pre-incubation with either one of five monoclonal antibodies (PP1/12, PP1/53, PP1/84, PP1/117 and PP1/134) or a tissue culture supernatant fluid containing no antibody (TCS)

\begin{tabular}{lrlllrr}
\hline Antibody & PP1 & PPA & PPB7 & PPD & PPE & PP3O \\
\hline PP1/12 & $6 \cdot 2$ & $2 \cdot 1$ & $5 \cdot 9$ & $7 \cdot 1$ & $10 \cdot 5$ & $10 \cdot 8$ \\
PP1/53 & $4 \cdot 0$ & $2 \cdot 1$ & $4 \cdot 7$ & $7 \cdot 3$ & $6 \cdot 3$ & $8 \cdot 2$ \\
PP1/84 & $11 \cdot 7$ & $2 \cdot 4$ & $6 \cdot 1$ & $7 \cdot 9$ & $11 \cdot 7$ & $10 \cdot 7$ \\
PP1/117 & $8 \cdot 1$ & $3 \cdot 2$ & $3 \cdot 8$ & $7 \cdot 1$ & $7 \cdot 1$ & $12 \cdot 1$ \\
PP1/134 & $7 \cdot 1$ & $3 \cdot 5$ & $6 \cdot 3$ & $8 \cdot 5$ & $8 \cdot 3$ & $13 \cdot 5$ \\
TCS (control) & $10 \cdot 7$ & $3 \cdot 3$ & $5 \cdot 3$ & $9 \cdot 0$ & $11 \cdot 2$ & $19 \cdot 4$ \\
\hline
\end{tabular}

ANOVA $P<0.001 ;$ S.E.D. $=1 \cdot 04$.

recognition of the concave surface of the spore which binds intimately with the nematode cuticle (Fig. 2), did not inhibit attachment to any greater extent than the other Mabs.

\section{Polyacrylamide gel electrophoresis and immunoblotting}

SDS-PAGE followed by Western blotting with the mouse polyclonal antiserum showed that the spores from different populations had very different banding profiles and differences could be seen at mol. wts $170,116,110,84,60,58$ and $50 \mathrm{kDa}$ (Fig. 3). When analogous blots were probed with the Mabs to the surface of the spores, no antigens were recognized, indicating the conformational nature of the epitopes recognized by the Mabs.

\section{Characterization of Pasteuria epitope ep117}

As no spore antigens were recognized by any of the monoclonal antibodies after SDS-PAGE and immunoblotting, it was decided to characterize one of the epitopes biochemically. Because Mab PP1/117 consistently visualized the concave surface of the spore during the early immunofluorescence studies, the experiments focused on this epitope which was designated ep117. Heat, Proteinase K, WGA, periodate, $N$ acetylglucosamine, fibronectin and fucose all reduced the recognition of ep 117 by PP1/117 by $75 \%$ or more. Trypsin, lysozyme, neuraminidase, mannose, xylose and galactose all had very little effect, reducing recognition of ep117 by less than $25 \%$; the other treatments had intermediate effects (Table 4).

\section{DISCUSSION}

Research into the use of Pasteuria for the control of plant parasitic nematodes has been stimulated by the recent concern 

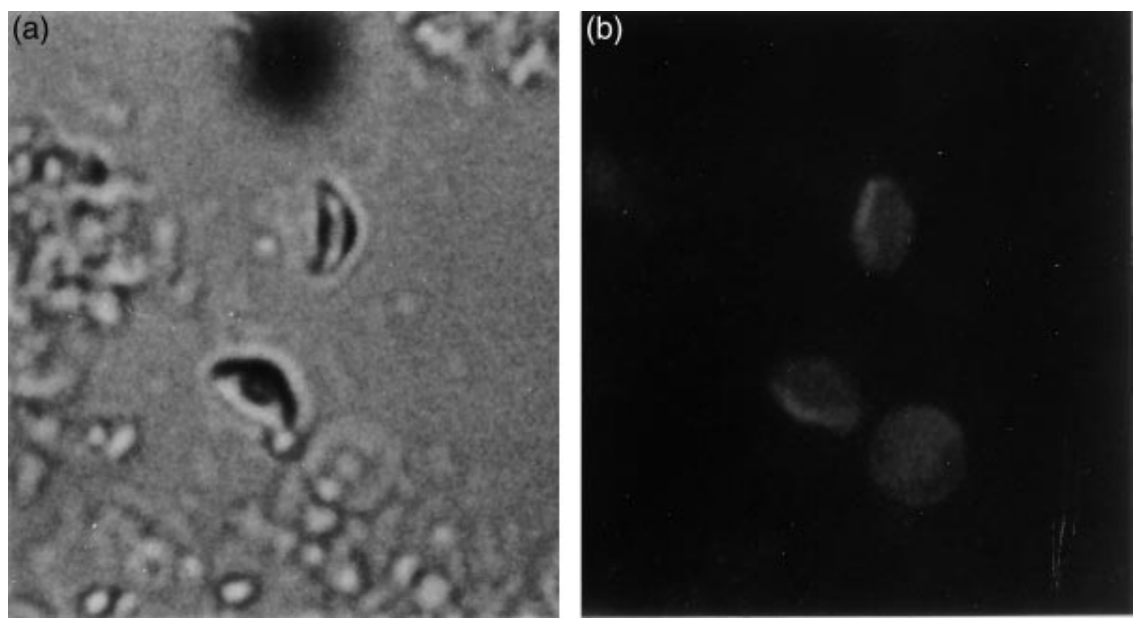

Fig. 2 Immunolocalization of the epitope ep117 recognized by Mab PP1/117 on spores of Pasteuria penetrans $(\times 1000)$ using $(a)$ brightfield and $(b)$ u.v. illumination with a $455 \mathrm{~nm}$ excitation filter and a $520 \mathrm{~nm}$ barrier filter; note the preferential recognition of the Mab for ep117 occurring on the concave surface of the spore, which is involved in the attachment process

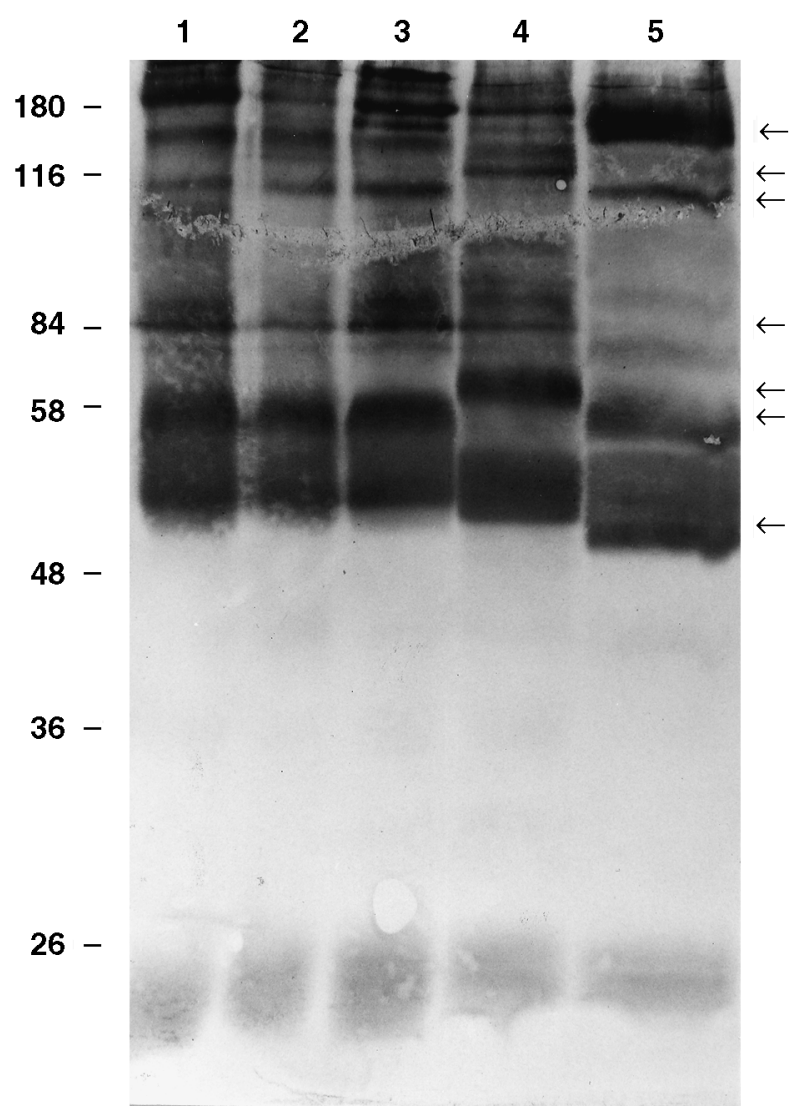

Fig. 3 SDS-PAGE of Pasteuria spore extracts (populations PP1, PNG, PCAL, PPE and PPD in lanes 1-5, respectively) followed by transfer onto nitrocellulose and probing with a polyclonal antiserum raised to whole spores of Pasteuria population PP1 (Persidis et al. 1992)

over the toxicity of nematicides and their fate in the environment (Thomason 1987). However, biological control studies have usually been done with the first isolate of the bacterium that was available which, not surprisingly, produced very variable levels of control. Basic studies are required to understand why isolates differ in their ability to attach to nematodes and how this relates to their virulence (Stirling 1991) before repeatable control can be obtained. It is now recognized that Gram-positive bacteria express on their surface adhesins which contribute to their virulence (Foster and McDevitt 1994; Patti et al. 1994). Our current knowledge of surface components of Gram-positive bacteria which interact with the extracellular environment is restricted to a relatively small number of pathogenic species (Kehoe 1994) and this study focuses on a Gram-positive bacterium, Pasteuria penetrans, which is very distinctive. In this study, we have attempted to identify several antigens recognized by monoclonal antibodies raised to the surface of $P$. penetrans, to assess the heterogeneity present between several populations of spores, and biochemically characterize one particular epitope.

The surface of $P$. penetrans population PP1 is highly heterogeneous and this heterogeneity is related to the ability of spores to adhere to different populations of nematodes (Davies et al. 1994). In this study, the surface antigens differed between different populations of spores but this did not reflect the geographical region from which the spore populations were originally isolated. Spore populations PP3O and PP3A originated from the same source in South Africa, but PP3A had been cultured on a population of Meloidogyne graminicola whereas PP3O had been cultured on M. incognita; on re-testing, PP3A did not adhere to its previous nematode host (S. R. Gowen, personal communication). The attachment profiles of spore populations PP1 and PPD were also similar to those of PP3O and PP3D; however, their antigenic profiles showed only $70 \%$ similarity. Spore populations PPD and PPE both originated in Australia and attached to a similar degree to M. incognita and M. arenaria (Davies et al. 1988) suggesting that they possessed common adhesins. However, Mab PP1/117, which recognized epitope ep117 on a large number of spores from population PPE, recognized very few spores of population PPD. Spore population PPA, which did 
Table 4 Indirect

immunofluorescence of 40 spores of Pasteuria (PP1) subjected to various physical and biochemical treatments together with appropriate untreated controls probed with monoclonal antibody PP1/117 (recognition was assessed as either positive or negative and the change in recognition in relation to the control treatments is given in the final column)

\begin{tabular}{|c|c|c|c|c|}
\hline \multirow[b]{2}{*}{ Treatments } & & \multicolumn{2}{|c|}{ Immunofluorescence } & \multirow[b]{2}{*}{$\%$ Change } \\
\hline & & + ve spores & - ve spores & \\
\hline Physical & Heat & 2 & 38 & -92 \\
\hline \multirow[t]{2}{*}{ Chemical } & $\mathrm{NaOH}$ & 14 & 26 & -42 \\
\hline & TCA & 9 & 31 & -63 \\
\hline Control & Water & 24 & 16 & \\
\hline \multirow[t]{2}{*}{ Proteolytic } & Trypsin & 28 & 12 & -7 \\
\hline & Proteinase K & 4 & 36 & -87 \\
\hline Control & Tris $\mathrm{pH} 7 \cdot 2$ & 30 & 10 & \\
\hline \multirow[t]{2}{*}{ Proteins } & Fibronectin & 7 & 33 & -77 \\
\hline & WGA & 0 & 40 & -100 \\
\hline Control & Tris $\mathrm{pH} 7 \cdot 2$ & 30 & 10 & \\
\hline \multirow[t]{4}{*}{ Glycolytic I } & Lysozyme & 27 & 13 & -7 \\
\hline & Chitinase & 16 & 24 & -45 \\
\hline & Galactosidase & 20 & 20 & -31 \\
\hline & Hyaluronidase & 21 & 19 & -28 \\
\hline Control & Tris $\mathrm{pH} 7 \cdot 2$ & 29 & 11 & \\
\hline \multirow[t]{2}{*}{ Glycolytic II } & Periodate & 0 & 40 & -100 \\
\hline & Neuraminidase & 20 & 20 & -9 \\
\hline Control & Acetate $\mathrm{pH} 5 \cdot 0$ & 22 & 18 & \\
\hline \multirow[t]{5}{*}{ Sugars } & Fucose & 3 & 37 & -90 \\
\hline & NAG & 7 & 33 & -76 \\
\hline & Mannose & 28 & 12 & -4 \\
\hline & Xylose & 25 & 15 & -14 \\
\hline & Galactose & 22 & 18 & -25 \\
\hline Control & Tris $\mathrm{pH} 7 \cdot 2$ & 29 & 11 & \\
\hline
\end{tabular}

not adhere well to any of the root-knot nematode populations tested (Davies et al. 1988), had a greater antigenic similarity to the other spore populations than did PPB7, which in attachment studies showed greater similarity to the other spore populations. These results therefore strongly indicate that attachment tests aimed at determining the biological variability present on the spore surface, by using a host nematode, appear to underestimate the amount of surface heterogeneity present compared to immunological techniques.

Mab PP1/84, which recognized very few spores irrespective of the population tested, had been found to recognize a very high proportion of those spores adhering to $M$. arenaria (Davies et al. 1994), suggesting either that the epitope to which it bound was involved in an interaction with a receptor which was restricted to $M$. arenaria or that it was closely associated with that epitope. It is therefore not surprising that PP1/84 did not reduce the binding of any of the spore populations to $M$. incognita tested here; presumably the speci- fic epitope is absent in the cuticle of this nematode. All the other Mabs reduced attachment of spores to the nematode cuticle in one or more of the Pasteuria populations. As no spore population was completely inhibited by the Mabs, the mechanism of attachment may be complex, and as none of the Mabs could detect their epitopes following SDS-PAGE and immunoblotting, this suggests each of the antigenic sites recognized by each particular Mab is conformational in nature.

Mab PP1/117 showed preferential recognition of the concave surface of the spore, which is involved in attachment and might therefore be expected to be more efficient at reducing attachment. The results showed it to be no more successful at inhibiting the attachment of spores than any of the other Mabs; in fact, in tests using the homologous spore population PP1, it was the least successful antibody. As attachment of spores is dependent on the nematode population being tested (Davies et al. 1994), the level of reduction in spore attachment caused by PP1/117 may reflect the distribution of the recep- 
tor on the nematode cuticle. In the same manner by which ep84 (identified by Mab PP1/84) on the spore surface appears to be associated with the ability of spores to attach to $M$. arenaria (Davies et al. 1994) and may be a virulence determinant, ep117 may be a virulence determinant but not for the population of $M$. incognita used during this investigation. These results therefore suggest that the distribution of any particular epitope differs not only between different spores but also between different populations, and that these may be predictive of virulence determinants for nematodes which possess the compatible receptor.

Although Mab PP1/117 would not have been our first choice in attempting to characterize the biochemical nature of its epitope (ep117), because it was not the most successful in inhibiting adhesion, from the practical point of view it gave the most clear cut results when using immunofluorescence techniques. Spores were subjected to a series of physical and chemical treatments to ascertain the biochemical nature of ep117. Although physical and chemical treatments are difficult to interpret due to their non-specific effects (Hancock and Poxton 1988), the denaturing of the epitope by heat and $\mathrm{NaOH}$ suggests that an $\mathrm{O}$-linked glycoprotein may be involved. This is further corroborated by the inability of PP1/117 to bind to spores after treatment with either Proteinase $\mathrm{K}$ or periodate and other workers have suggested similar mechanisms (Persidis et al. 1991). The antibody was also competitively inhibited from binding to the spores by WGA, fucose and $N$-acetylglucosamine; all these treatments had previously been shown to reduce the ability of spores to adhere to the cuticles of nematodes (Davies and Danks 1993). Fibronectin is a component of the extracellular matrix of many animals and has been shown to be important in the adhesion of many Gram-positive bacteria in infection (Hasty et al. 1989; Courtney et al. 1990). Recent work showed it bound to spores of Pasteuria through hydrophobic interactions, inhibiting the attachment of spores to the nematode cuticle (Davies et al. 1996) and it clearly competed with PP1/117 and prevented it from recognizing its epitope. Early studies hypothesized that glycoproteins, namely $N$-acetylglucosamine, present on the spore surface interact with a receptor on the nematode cuticle (Persidis et al. 1991; Davies et al. 1992), and further evidence in support of this was observed when chitinase reduced spore attachment (Davies and Danks 1993). Although chitinase reduced the recognition of ep117 by its antibody to a small extent, the fact that the adhesin is conformational and host specific suggests the hypothesis is too simple. It has been shown through negative staining that the surface of Pasteuria contains long fibrils radiating out from the spore surface; these fibrils were shown to be BME-soluble glycoproteins containing a high level of $N$-acetylglucosamine, and were thought to be involved with adhesion (Persidis et al. 1991). Therefore, these results suggest that the model of a carbohydrate/protein interaction involving glycoproteins, in particular the involvement of $N$ acetylglucosamine (Davies and Danks 1993), to describe the mechanism of attachment of the spore to the bacterium is not valid. The conformational nature of the epitopes recognized by the Mabs, together with their distribution on the surface of the spore, suggest that the environment, in particular the hydrophobicity in which the fibrils exist may also be very important in determining whether or not a spore will attach to a particular nematode.

\section{ACKNOWLEDGEMENTS}

Institute of Arable Crops Research receives grant-aided support from the Biotechnological and Biological Sciences Research Council of the United Kingdom and MR was funded through an EU project (TS3 CT92-0098) coordinated by Dr D. L. Trudgill.

\section{REFERENCES}

Afolabi, P., Davies, K.G. and O'Shea, P.S. (1995) The electrostatic nature of the spore of Pasteuria penetrans, the bacterial parasite of root-knot nematodes. Fournal of Applied Bacteriology 79, 244-249.

Anon. (1987) Genstat 5 Committee, Reference Manual. Oxford: Clarendon Press.

Bird, A.F., Bonig, I. and Bacic, A. (1989) Factors affecting the adhesion of micro-organisms to the surfaces of plant-parasitic nematodes. Parasitology 15, 301-308.

Channer, A.G. De R. and Gowen, S.R. (1992) Selection for increased host resistance and increased pathogen specificity in the Meloidogyne-Pasteuria penetrans interaction. Fundamental and Applied Nematology 15, 331-339.

Courtney, H.S., Hasty, D.L. and Ofek, I. (1990) Hydrophobicity of Group A streptococci and its relationship to adhesion of streptoccoci to host cells. In Microbial Cell Hydrophobicity ed. Doyle, R.J. and Rosenberg, M. pp. 361-386. Washington, DC: American Society for Microbiology.

Davies, K.G. (1994) A nematode case study focusing on the application of serology. In Identification and Characterisation of Pest Organisms ed. Hawksworth, D.L. pp. 395-413. Wallingford: CAB International.

Davies, K.G. and Danks, C. (1992) Interspecific differences in the nematode surface coat between Meloidogyne incognita and $M$. arenaria related to the adhesion of the bacterium Pasteuria penetrans. Parasitology 105, 475-480.

Davies, K.G. and Danks, C. (1993) Carbohydrate/protein interactions between the cuticle of infective juveniles of Meloidogyne incognita and spores of the obligate hyperparasite Pasteuria penetrans. Nematologica 39, 53-64.

Davies, K.G., Flynn, C.A. and Kerry, B.R. (1988) The life-cycle and pathology of the root-knot nematode parasite Pasteuria penetrans. Proceedings of the British Crop Protection Conference - Pests and Diseases 3, 1221-1226.

Davies, K.G., Robinson, M.P. and Laird, V. (1992) Proteins on the surface of spores of Pasteuria penetrans and their involvement in 
attachment, to the cuticle of second-stage juveniles of Meloidogyne incognita. Fournal of Invertebrate Pathology 59, 18-23.

Davies, K.G., Pearson, T. and Redden, M. (1994) Endospore heterogeneity in Pasteuria penetrans related to adhesion to plant parasitic nematodes. Letters in Applied Microbiology 19, 370-373.

Davies, K.G., Afolabi, P. and O'Shea, P.S. (1996) Adhesion of Pasteuria penetrans to the cuticle of root-knot nematodes ( $\mathrm{Mel}-$ oidogyne spp.) inhibited by fibronectin: a study of electrostatic and hydrophobic interactions. Parasitology 112, 553-559.

Digby, P.G.N. and Kempton, R.A. (1987) Multivariate Analysis of Ecological Communities. pp. 124-149. London: Chapman \& Hall.

Foster, T.J. and McDevitt, D. (1994) Surface-associated proteins of Staphylococcus aureus: their possible roles in virulence. FEMS Microbiology Letters 118, 199-206.

Frank, S.A. (1994) Recognition and polymorphism in host-parasite genetics. Philosophical Transactions of the Royal Society of London B 346, 283-293.

Hancock, I.C. and Poxton, I.R. (1988) Bacterial Cell Surface Techniques. Chichester: John Wiley \& Sons.

Harlow, E. and Lane, D. (1988) Antibodies: A Laboratory Manual. Cold Spring Harbor, NY: Cold Spring Harbor Laboratory Press.

Hasty, D.L., Beachey, E.H., Courtney, H.S. and Simpson, W.A. (1989) Interactions between fibronectin and bacteria. In Fibronectin in Health and Disease ed. Carsons, S.E. pp. 89-112. Boca Raton, FL: CRC Press.

Hewlett, T.E. and Dickson, D.W. (1993) A centrifugation method for attaching endospores of Pasteuria spp. to nematodes. Fournal of Nematology 25 (Suppl.), 785-788.

Hooper, D.J. (1986) Extraction of nematodes from plant material. In Laboratory Methods for Work with Plants and Soil Nematodes ed. Southey, J.F. pp. 51-58. Ministry of Agriculture Fisheries and Food. London: HMSO.

Kehoe, M.A. (1994) Cell-wall-associated proteins in Gram-positive bacteria. In Bacterial Cell Wall ed. Ghuysen, J.-M. and Hakenbeck, R. pp. 217-261. New York: Elsevier.

Luc, M., Maggenti, A.R. and Fortuner, R. (1988) A reappraisal of Tylenchina (Nemata). 9. The family Heteroderidae Filip'ev \& Schuurmans Stekhoven (1941). Revue de Nematologie 11, 159 176.

Maizels, R.M., Blaxter, M.L. Robertson, B.D. and Selkirk, M.E.
(1991) Parasite Antigens and Parasite Genes: A Laboratory Manual for Molecular Parasitology. p. 224. Cambridge University Press.

Oostendorp, M., Dickson, D.W. and Mitchell, D.J. (1991) Population development of Pasteuria penetrans on Meloidogyne arenaria. Journal of Nematology 23, 58-64.

Patti, J.M., Allen, B.L., McGavin, M.J. and Höök, M. (1994) MSCRAMM-mediated adherence of microorganisms to host tissues. Annual Reviem of Microbiology 48, 585-617.

Persidis, A., Lay, J.G., Manousis, T., Bishop, A.H. and Ellar, D.J. (1991) Characterisation of potential adhesins of the bacterium Pasteuria penetrans, and of putative receptors on the cuticle of Meloidogyne incognita, a nematode host. Fournal of Cell Science 100, 613-622.

Sayre, R.M. and Starr, M.P. (1985) Pasteuria penetrans (ex Thorne 1940) nom. rev., comb., n., sp., n., a mycelial endospore-forming bacterium parasitic in plant-parasitic nematodes. Proceedings of the Helminthological Society of Washington 52, 149-165.

Sayre, R.M. and Starr, M.P. (1988) Bacterial diseases and antagonisms of nematodes. In Diseases of Nematodes ed. Poinar, G.O. and Jansson, H.B. Vol. 1, pp. 69-101. Boca Raton, FL: CRC Press.

Sayre, R.M., Gherna, R.L. and Wergin, W.P. (1983) Morphological and taxonomic reevaluation of Pasteuria ramosa Metchnicoff 1888 and Bacillus penetrans Mankau 1975. International Fournal of Systematic Bacteriology 33, 636-649.

Sayre, R.M., Wergin, W.P., Schmidt, J.M. and Starr, M.P. (1991) Pasteuria nishizamae sp. nov., a mycelial and endospore-forming bacterium parasitic on cyst nematodes of genera Heterodera and Globodera. Research in Microbiology 142, 551-564.

Stirling, G.R. (1985) Host specificity of Pasteuria penetrans within the genus Meloidogyne. Nematologica 31, 203-209.

Stirling, G.R. (1991) Biological Control of Plant-parasitic Nematodes: Progress, Problems and Prospects. p. 282. Wallingford: CAB International.

Stirling, G.R. and Wachtel, M.F. (1980) Mass production of Bacillus penetrans for the biological control of root-knot nematodes. Nematologica 26, 308-312.

Thomason, I.J. (1987) Challenges facing nematology: environmental risks with nematicides and the need for new approaches. In Vistas of Nematology ed. Veech, J.A. and Dickson, D.W. pp. 469-476. Hyattsville, MD: Society of Nematologists, Inc. 